\begin{tabular}{|r|c|c|}
\hline Received: October 2017 & Accepted: January 2018 & Published: April 2018 \\
\hline \multicolumn{2}{|c|}{ Article DOI: $\underline{\text { http://dx.doi.org/10.24903/sj.v3i1.148 }}$} \\
\hline
\end{tabular}

\title{
The Use of Cooperative Learning Through Tai (Team Assisted Individualization) In Reading Comprehension
}

\author{
Ermawati Z Nuroh \\ Universitas Muhammadiyah Sidoarjo \\ ermawati@umsida.ac.id \\ Vidya Mandarani \\ Universitas Muhammadiyah Sidoarjo \\ vmandarani@umsida.ac.id
}

\begin{abstract}
Cooperative Learning is a teaching arrangement that refers to small, heterogeneous groups of students working together to achieve a common goal (Kagan, 1994). This research is done to know the response of students used cooperative learning in reading comprehension. The data of this study analyzed qualitatively without applying statistical calculations. The subject of the study were the students of the first semester in Midwifery faculty of Universitas Muhammadiyah Sidoarjo. There researcher used one class which consist 29 students. The students gave the positive responses and dominantly agreed to the implementation of cooperative learning type Team Assisted Individualization (TAI) in reading comprehension. From the questionnaire, the researcher concludes that are $40 \%$ students are agreed, 50\% students strongly agree, and $10 \%$ less agree with cooperative learning type Team Assisted Individualization (TAI) in reading comprehension. The conclusion is students respond well to cooperative learning model type Team Assisted Individualization (TAI) to improve students' reading comprehension. This cooperative learning type Team Assisted Individualization (TAI) can be the one of the model to teach reading comprehension.
\end{abstract}

Keywords: Cooperative learning, Team Assisted Individualization, Reading comprehension 


\section{INTRODUCTION}

Education in Indonesia has the big challenge especially in developing the education in globalization era. In this era the students have many challenges in education competition. Curriculum plays an important role in the development of education. The curriculum is an educational program that contains various teaching materials, programmed learning experiences, planned, and systematically designed on the basis of applicable norms, used as guidelines in the learning process for educational staff, and learners to achieve educational goals.

In English Learning, based on the curriculum, there are four abilities that must be mastered by students; among them are listening skill, speaking skill, writing skill, and reading skill. Of the four skills students must be active in learning that is by using the student's center learning. Classes that are still teacher-centered give lectures will lead to passive students in the classroom and do not get the most out of the skill.

In all levels of education in Indonesia, the satisfaction of four English language learning skills still has many difficulties, especially in understanding reading comprehension. In reading comprehension students learn how to find, and master the content of reading. At class, students are trained to understand reading but still have serious problems for most Indonesian students. The ability to read is strongly influenced by the ability of vocabulary mastery and reading habits possessed by students so as to understand the reading easily.

The research from Jalilifar (2010) Student Team Achievement Divisions (STAD) is a more effective technique in improving EFL reading comprehension achievement whereas Group Investigation (GI) and Conventional Instruction (CI) did not enhance reading comprehension significantly. Team rewards, as one of the central concepts of STAD, may have a strong impact on learners' performance in reading comprehension.

One of the learning models that can facilitate in reading comprehension is cooperative learning model. Cooperative learning refers to any kinds of teaching methods in which the students work together in small groups for helping each other in learning a certain lesson material (Slavin, 2008: 4). The students work together can be the one solution for the student to share the understanding of the reading text.

Cooperative Learning is a teaching arrangement that refers to small, heterogeneous groups of students working together to achieve a common goal (Kagan, 1994). Heterogeneous means that in one group there will be students with high and low ability. There are several variations of cooperative learning model, such as Team Assisted 
Individualization (TAI) combines cooperative learning with individualized instruction (Slavin, 2008).

Asih and Nugroho (2012) in their research of the implementation of TAI technique in the teaching reading comprehension of descriptive text to the seventh grade students was successfully implemented in one junior high school in Kediri, East Java. The teacher modified and adapted the theory of TAI implementation. The students' shows a good response toward the implementation of the TAI technique in the teaching learning process. Most of the students mentioned that they enjoy learning reading descriptive text while TAI technique was implemented. During the technique implementation the students can learn about toleration, responsibility, and teamwork character that is beneficial for them. Indeed, the technique implementation can be applied successfully due to the teacher and the students' cooperation that refers to the TAI technique.

Reading comprehension problems are also faced by students of the first semester of D3 Midwifery program of Universitas Muhammadiyah Sidoarjo, especially in special texts about midwifery. Understanding vocabulary that is still weak and the ability to understand the content of the reading still become the main problem for the students. Therefore there should be a learning model that can solve the problem of reading comprehension students learning in understanding the text about midwifery.

Based on the research that has been done on the first semester students of Diploma 3 Midwifery of Universitas Muhammadiyah Sidoarjo on cooperative learning, it is very necessary to find the response to the implementation of cooperative learning. Because it is very important to know the response of students to know to what extent cooperative learning can help students in reading comprehension learning.

\section{METHODOLOGY}

The data of this study analyzed qualitatively without applying statistical calculations. The researchers used participant observation because the researchers take part in the teaching learning process. Another researcher also observed the students' activity in the class and reported from the beginning until the end of the lesson. Second, she did the interview the students to get the information about the student's attitude and difficulties and at the last meeting the researcher gave the questionnaire to gain the information does the students like or dislike, interest or not when they learn English especially in reading comprehension through cooperative learning type Team Assisted Individualization (TAI). The subject of the 
study were the students first semester of D3 Midwifery Program of Universitas Muhammadiyah Sidoarjo. There researcher used one class which consist 29 students.

The instrument of this study is observation sheet and questionnaire. The researcher used the observation sheet to help describe the phenomena that intercourse with the implementation of cooperative learning cooperative learning type Team Assisted Individualization in reading comprehension. Questionnaire are analysing to gain information dealing with the student's motivation, interest, and the student's response toward the implementations of cooperative learning type Team Assisted Individualization (TAI) in reading comprehension. The likert scale used to measure the attitude, opinion and perception an indiviual or some of group about the social phenomenon (Sugiyono, 2011:93). In this study, the researcher used the likert scale for the questionnaire and used this formula in analysing data obtained from the questionnaire as follow :

$$
\mathrm{P}=\frac{n}{N} x 100 \%
$$

In which :

$\mathrm{P}=$ percentage of questionnaire

$\mathrm{n}=$ the number of respondents who answer yes or no

$\mathrm{N}=$ the total number of respondents

The technique used to collect the data in this study was observation and questionnaire. This was done to describe the data. The materials of reading text were selected then those materials were observed to get data. The data of this research generate mainly from the questionnaire that the researcher gave for all of the students in the class, while the source of the data were Midwifery students in the first semester of Universitas Muhammadiyah Sidoarjo. In this study, the researcher collected the data through non-participant observation. Non-participant observation is an observation in which the researcher is getting involved in the process of teaching and learning. The researcher should be kept existence but not influencing the natural attitude or behaviorism of the subject of the study.

\section{FINDINGS AND DISCUSSION}

This session contains the result of the student's response about cooperative learning type Team Assisted Individualization in reading comprehension.

\begin{tabular}{|l|l|l|l|l|l|l|l|l|}
\hline $\begin{array}{l}\text { Questionnaire } \\
\text { statement }\end{array}$ & 1 & 2 & 3 & 4 & 5 & 6 & 7 & 8 \\
\hline
\end{tabular}




\begin{tabular}{|ll|l|l|l|l|l|l|l|l|}
\hline $\mathrm{N}$ & Valid & 29 & 29 & 29 & 29 & 29 & 29 & 29 & 29 \\
& Missing & 0 & 0 & 0 & 0 & 0 & 0 & 0 & 0 \\
\hline
\end{tabular}

Table 1. Questionnaire Frequencies statistics

Table 1 shows the result of the questionnaire frequencies statistics from 29 students and the result is valid. Below are the findings of every question in questionnaire.

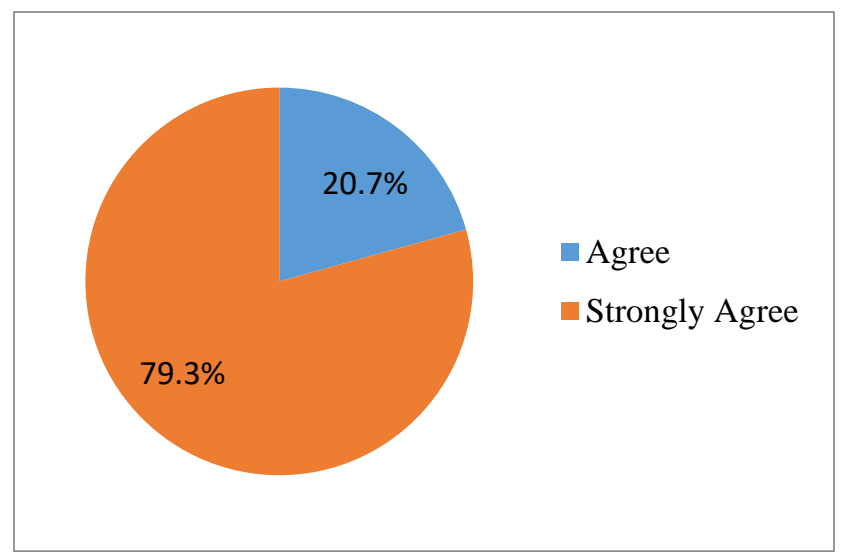

Figure 1. Lecturers need an appropriate learning strategy for teaching and learning activities

From the figure 1 above, it was shown from the percentage between strongly agree and agree. There were $79.3 \%$ students responses strongly agree about the lecturers need an appropriate learning strategy for teaching and learning activities. There were $20.7 \%$ students responses agree about the lecturers need an appropriate learning strategy for teaching and learning activities.

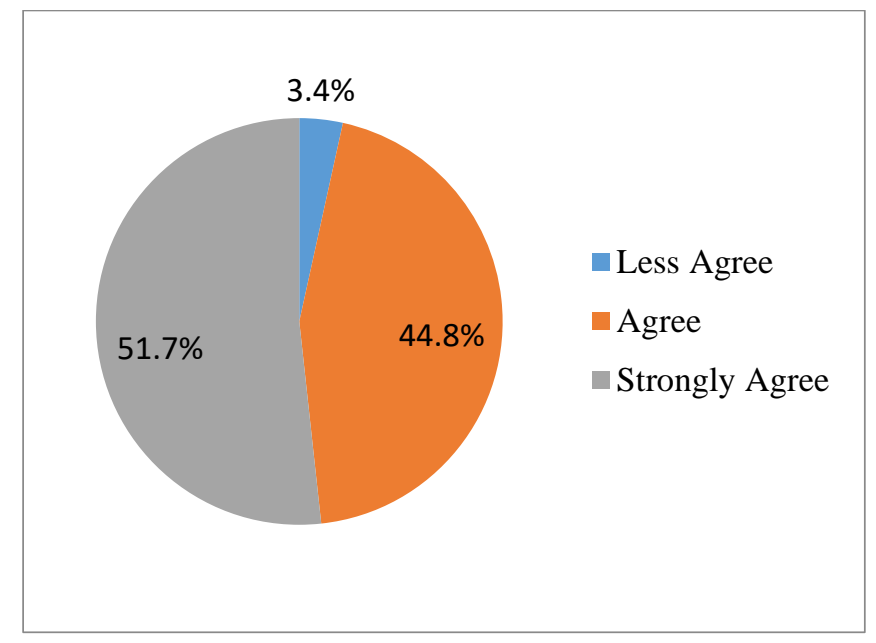

Figure 2. Students often feel bored with the monotonous learning activities

From Figure 2 above, it was shown that the student strongly agree often feel bored with the monotonous learning activities is $51.7 \%$. Students agree often feel bored with the monotonous learning activities is $44.8 \%$ and less agree $3.4 \%$. 


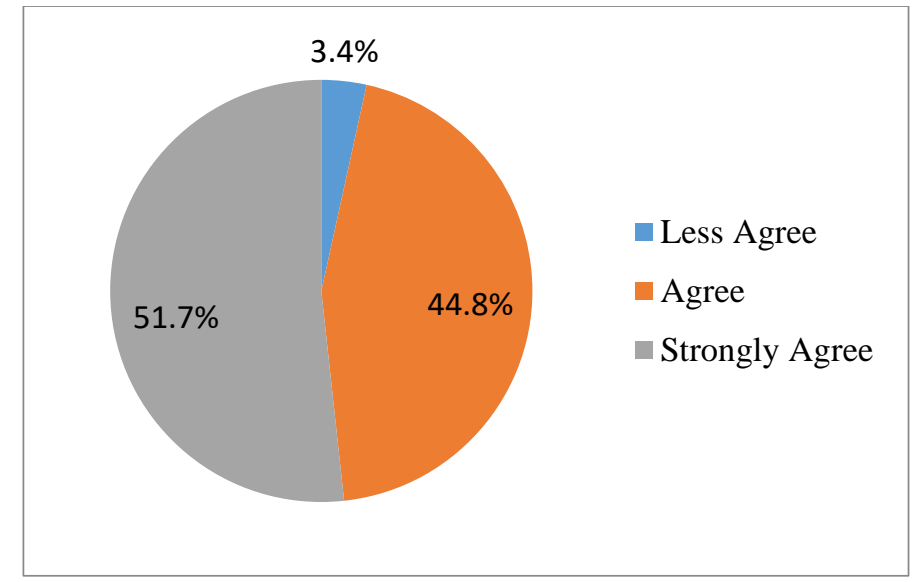

Figure 3. Cooperative learning type TAI can improve students' comprehending of reading

From figure 3 above, it was shown there were $51.7 \%$ students' responses strongly agree that cooperative learning type Team Assisted Individualization (TAI) can improve students' comprehending of reading. There were $44.8 \%$ students' responses agree that cooperative learning type Team Assisted Individualization (TAI) can improve students' comprehending of reading. There were $3.4 \%$ students' responses less agree that cooperative learning type Team Assisted Individualization (TAI) can improve students' comprehending of reading.

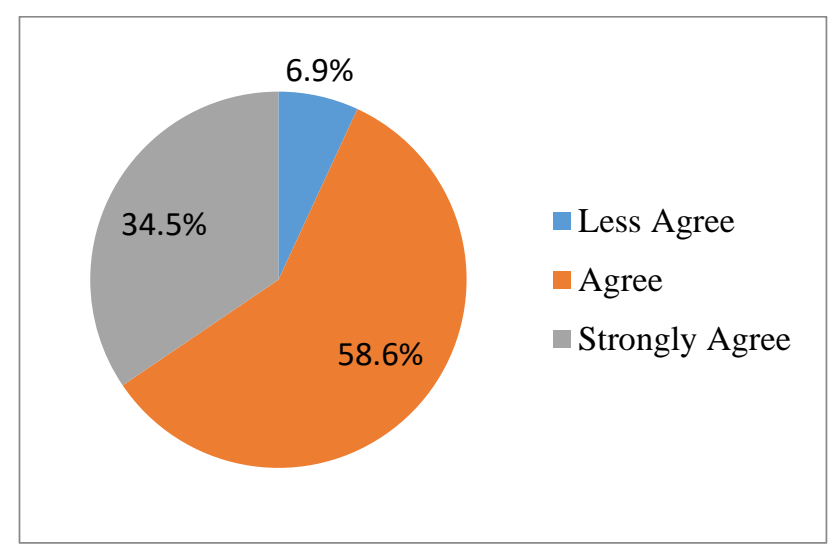

Figure 4. Cooperative learning type TAI makes teaching and learning activities more enjoyable

From Figure 4 above, it was shown there were 58.6\% students' responses agree cooperative learning type Team Assisted Individualization makes teaching and learning activities more enjoyable. There were $34.5 \%$ students' responses strongly agree cooperative learning type Team Assisted Individualization makes teaching and learning activities more enjoyable. There were $6.9 \%$ students' responses less agree cooperative learning type Team Assisted Individualization makes teaching and learning activities more enjoyable. 




Figure 5. Cooperative learning type TAI makes students become more active in teaching and learning activities

From figure 5 above, it was shown there were $62.1 \%$ students' responses agree cooperative learning type Team Assisted Individualization makes students more active in teaching and learning activities. There were $31.0 \%$ students' responses strongly agree cooperative learning type Team Assisted Individualization makes students more active in teaching and learning activities. There were $6.9 \%$ students' responses less agrees cooperative learning type Team Assisted Individualization makes students more active in teaching and learning activities.

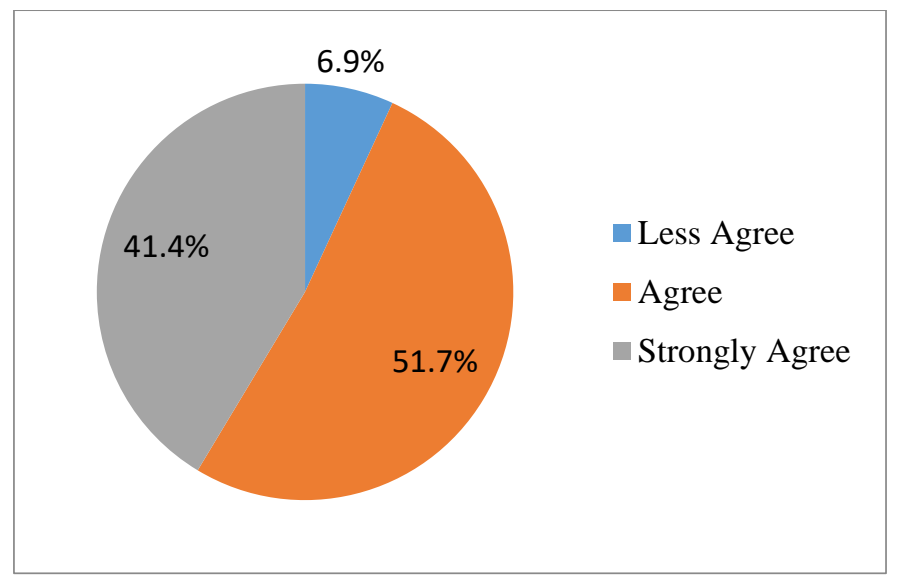

Figure 6. Cooperative learning type TAI is able to improve students' ability in team work

From Figure 6 above, it was shown there were $51.7 \%$ students' responses agree cooperative learning type Team Assisted Individualization (TAI) is able to improve students' ability in team work. There was $41.4 \%$ students' responses strongly agree cooperative learning type Team Assisted Individualization (TAI) is able to improve students' ability in team work. There were $6.9 \%$ students' responses less agree cooperative learning type Team Assisted Individualization (TAI) is able to improve students' ability in team work. 


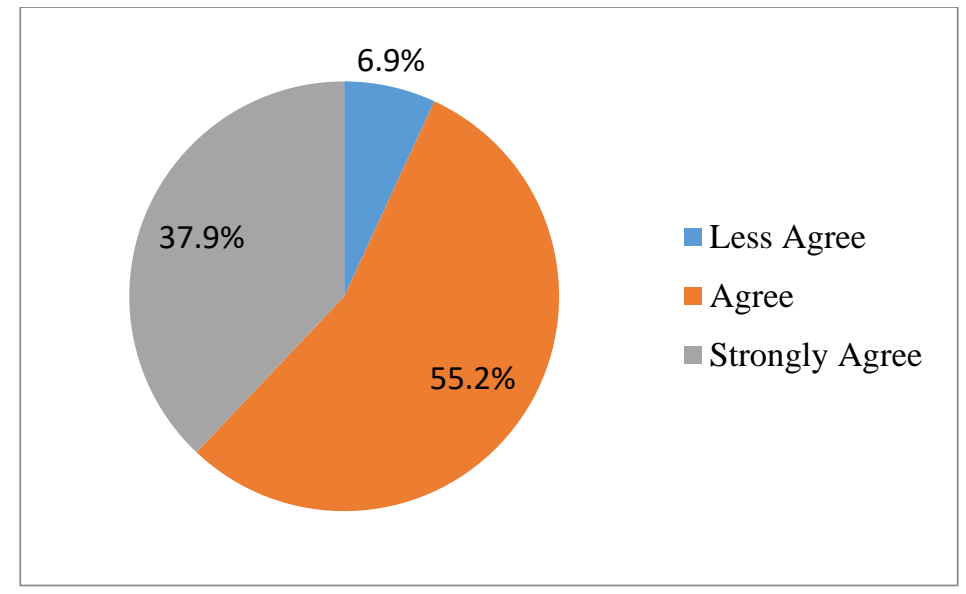

Figure 7. Cooperative learning strategy type TAI is able to improve the students responsibly in a group

From Figure 7 above, it was shown there were 55.2\% students' responses agree cooperative learning type Team Assisted Individualization (TAI) is able to improve students' responsibly in the group. There were $37.9 \%$ students' responses strongly agree cooperative learning type Team Assisted Individualization (TAI) is able to improve students' responsibly in the group. There were $6.9 \%$ students' responses agree cooperative learning type Team Asissted Individualizatition (TAI) is able to improve students' responsibly in the group.

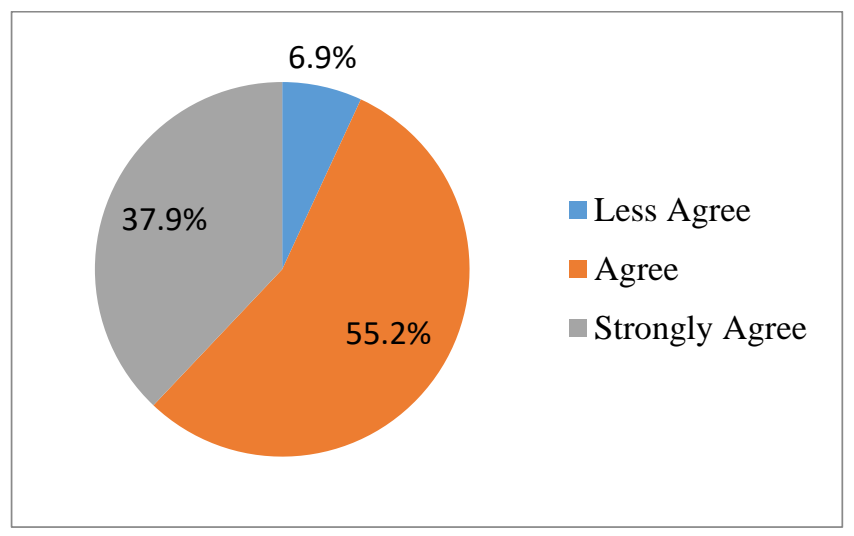

Figure 8. Cooperative learning strategy type TAI able to improve student motivation to read

From Figure 8 above, it was shown there were $55.2 \%$ students' responses agree cooperative learning type Team Assisted Individualization (TAI) is able to improve students' motivation to read. There was $37.9 \%$ students' responses agree cooperative learning type Team Assisted Individualization (TAI) is able to improve students' motivation to read. There was $6.9 \%$ students' responses agree cooperative learning type Team Assisted Individualization (TAI) is able to improve students' motivation to read.

From the data, it shows that the researcher got the result of the questionnaire and the percentage of the figure. The students gave the positive responses with the implementation of cooperative learning type Team Assisted Individualization in reading comprehension. They felt that cooperative learning type Team Assisted Individualization (TAI) was helpful them to 
comprehend reading text. The students often feel bored with the monotonous learning activity so that the lecturers need an appropriate learning strategy for teaching and learning activities. The writer used cooperative learning type Team Assisted Individualization to improve students' comprehending of reading text. Cooperative learning type Team Assisted Individualization made the students more enjoyable and motivated to learn to read text in the class that was proved from their score.

The research from Andreassen (2011) indicated that during a five-month intervention period, students in the intervention group increased their strategic competence and comprehension performance relative to controls. In line with Marzban (2014) research about the effect of Cooperative Learning (CL) on reading proficiency at class. He did the pretest, treatment, and the posttest. Finally the analysis of t-test was used to find the statistical answer for the above mentioned question and the $\mathrm{p}$ value obtained (0.000) showed that the experimental groups had better results. It shows that Cooperative learning type Team Assisted Individualization made the students become more active in teaching and learning activities. By cooperative learning type team assisted individualization (TAI), the students' ability in teamwork more improve and have responsibility in their group.

\section{CONCLUSION}

The students gave the positive responses and dominantly agreed to the implementation of cooperative learning type Team Assisted Individualization (TAI) in reading comprehension. From the questionnaire, the researcher concludes that are $40 \%$ students are agreed, 50\% students strongly agree, and 10\% less agree with cooperative learning type Team Assisted Individualization (TAI) in reading comprehension. The students enjoyed, fun and interested when they learn English by using cooperative learning type Team Assisted Individualization (TAI). So it can be concluded that students respond well to cooperative learning model type Team Assisted Individualization (TAI) to improve students' reading comprehension. 


\section{BIBLIOGRAPHY}

A, M., \& F, A. (2014). The Effect of Cooperative Learning on Reading Comprehension of Iranian EFL Learners. Procedia, 116(1), 3744-3748.

Asih, M., \& Nugroho, A. . (2016). Teaching Descriptive Reading Comprehension Using Team Assisted Individualization (TAI) to the Seventh Grade Students. RETAIN, 4(1), 111.

Jalilifar, A. (2010). The effect of cooperative learning techniques on college students' reading comprehension. System, 38(1), 96-108.

Kagan, S. (1994). Cooperative Learning. San Clemente: CA: Kagan Publishing.

R, A., \& I, B. (2011). Implementation and effects of explicit reading comprehension instruction in fifth-grade classrooms. Learning and Instructions, 21(4), 520-537.

Slavin, E. R. (2008). Cooperative Learning Teori Riset dan Praktik. Bandung: Nusa Media.

Sugiyono. (2011). Metode penelitian kuntitatif kualitatif dan $R \& D$. Alfabeta. 